\title{
New chiral polyfunctional cyclobutane derivatives from (-)-verbenone: possible surfactant behaviour
}

\author{
Jimena Ospina, ${ }^{\mathrm{a}}$ Alessandro Sorrenti, ${ }^{a}$ Ona Illa, ${ }^{\mathrm{a}}$ Ramon Pons ${ }^{\mathrm{b} *}$ and Rosa M. Ortuño ${ }^{\mathrm{a}, *}$ \\ ${ }^{a}$ Departament de Química, Universitat Autònoma de Barcelona, 08193 - Cerdanyola del Vallès, Spain \\ ${ }^{b}$ Departament de Tecnologia Química i de Tensioactius, Institut de Química Avançada de Catalunya, \\ IQAC-CSIC, c/Jordi Girona 18-26, 08034 - Barcelona, Spain
}

*Corresponding author: Tel.: +34 935811602

E-mail address: rosa.ortuno@uab.es (R.M. Ortuño). 


\begin{abstract}
New enantiopure cyclobutane derivatives have been synthesized from a chiral precursor derived from ()-verbenone. The cyclobutane moiety acts as a chiral ramified platform affording a $\gamma$-amino acid function in a branched side-chain containing an additional stereogenic centre as well as additional $C_{6}$ or $C_{16}$-alkyl chains linked to the ring by means of an amine or an amide function. One of these compounds, obtained as a 1:2 mixture with its TFA salt, has been investigated suggesting behaviour as a good surfactant and its critical micellar concentration has been determined.
\end{abstract}




\section{Introduction}

Surfactants constitute one of the chemicals groups of molecules that are most widely used. Their applications range from detergents to cosmetics, drug and food additives, and more recently they are applied in drug delivery systems. Some of them are useful in industrial processes such those related with petrochemistry, chromatography, catalysis among others. Research is now undergoing in fields of high technology like microelectronics and biotechnology, and also in biomedicine. ${ }^{1}$

Surfactants are "surface active agents". This term is used to describe those molecules that tend to diminish the superficial tension of an interface, namely water-air or fat-water. Their structure always implies having differentiated parts of the molecule with opposite solubility, usually an alkyl chain, which is soluble in non polar solvents (hydrophobic part), and a functional group that has a high affinity for polar solvents (hydrophilic part). These molecules apart from adsorption also show self-aggregation. Classically, the maximum adsorption is achieved around the same concentration at which aggregates form in the bulk solution. The surface tension, which is related to the amount of adsorbed material through the Gibbs adsorption isotherm, tends to level above the critical micellar concentration because the monomer activity tends to remain constant.

Amino acid based surfactants are of relevant importance ${ }^{2}$ due to their good levels of biodegradability and biocompatibility. ${ }^{3}$ The combination of amino acids or peptides with hydrocarbon chains of variable length has given rise to a variety of compounds with amphiphilic structure with good surfactant properties. Most of the examples imply the use of natural $\alpha$-amino acids.

Another important aspect is chirality in the surfactants. This issue has been exploited especially for their use as templates in the synthesis of silica materials, ${ }^{4}$ as deracemization agents, ${ }^{5}$ in chiral electromigration chromathography techniques ${ }^{6}$ amongst others. In the case of amino acid based surfactants, chirality is directly related to some of their physicochemical and biological properties.

Our group has experience in the synthesis and structural study of enantiopure cyclobutane containing amino acids and peptides, where the cyclobutane ring has a role as an element of constrain. Starting from chiral pool precursors such as (-)-verbenone and (-)- $\alpha$-pinene, enantiopure building blocks ${ }^{7}$ have been prepared and used in the synthesis of several derivatives including amino ethers with analgesic 
activity, ${ }^{8} \alpha$-dehydroamino acids, ${ }^{9}$ and different types of unnatural saturated amino acids. ${ }^{10}$ From some of these scaffolds, a wide variety of products have been synthesized namely: $\beta$-peptides, ${ }^{11} \gamma$-peptides, ${ }^{12} \gamma$ lactams and cyclobutyl GABA analogues, ${ }^{13}$ hybrid peptides with cell-uptake properties ${ }^{14}$ and $C_{3^{-}}$ symmetric dendrimers. ${ }^{15}$ Some of these compounds aggregate giving vesicles ${ }^{14}$ or show properties as organogelators. $^{15}$

In this work, we describe the stereoselective synthesis of two types of chiral cyclobutane containing $\gamma$ amino acids in which the cyclobutane ring is not a part of the amino acid main skeleton but acts as a chiral ramified platform bearing the appropriate functional groups and side-chains. These include a $C_{16^{-}}$ alkyl chain that, jointly with the gem-dimethyl group of the cyclobutane, confers hydrophobicity to the molecule. Both amino acids differ in that the chain is linked to the cyclobutane moiety by means of an amine or an amide function (Chart 1). The physicochemical characterization and properties of this new class of surfactants was investigated and some results are reported and discussed herein.

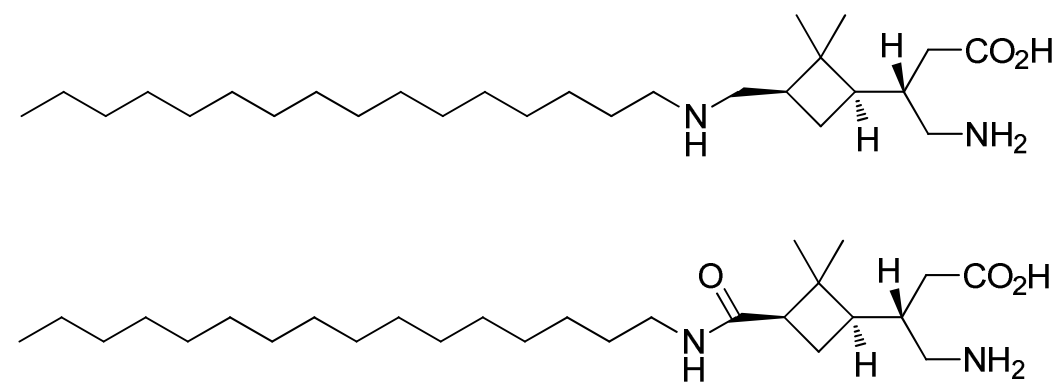

Chart 1. Types of surfactants envisioned

\section{Results and discussion}

\subsection{Synthesis}

The two types of amino acid derivatives were prepared through divergent synthetic ways starting from the common chiral precursor $\mathbf{1}$, which is a $\gamma, \varepsilon$ - amino diacid that had previously been synthesized in our laboratory from (-)-verbenone $\mathrm{e}^{12 \mathrm{~b}}$ (Scheme 1). This compound presents a side-chain containing the orthogonally protected $\gamma$-amino acid and bearing an additional stereogenic centre with determined absolute configuration at the $\beta$-carbonyl position. Moreover, the carboxyl group can be transformed in a functional group suitable to introduce the alkyl chain. An amine and an amide, respectively, were 
envisioned for this purpose. In the former case, hexadecylamine was reacted, via a $S_{N} 2$ mechanism, with an appropriate derivative of the primary alcohol resultant from reduction of the carboxylic acid. In the second case, hexadecylamine was coupled with 1 via the formation of an acid chloride.
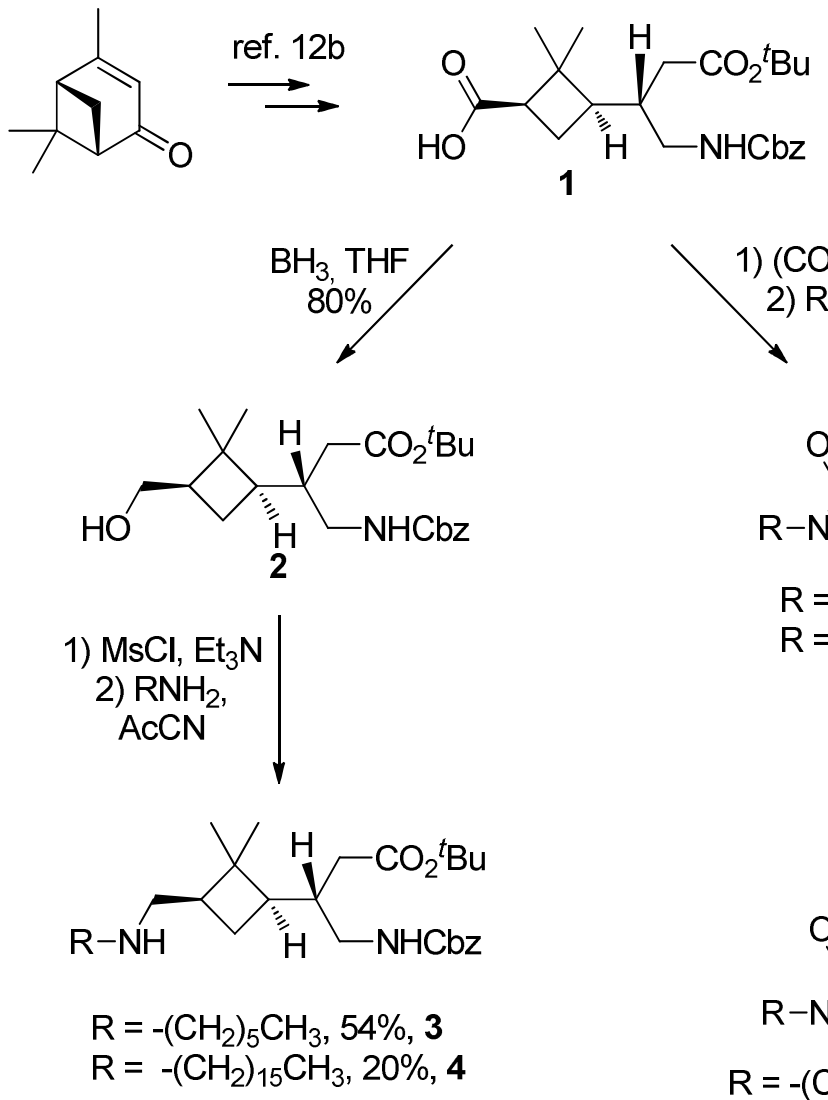

2) $\mathrm{RNH}_{2}, \mathrm{Et}_{3} \mathrm{~N}$

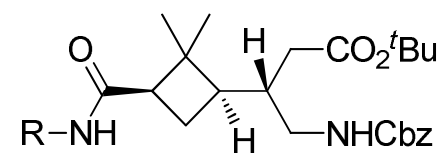

$$
\begin{aligned}
& \mathrm{R}=-\left(\mathrm{CH}_{2}\right)_{5} \mathrm{CH}_{3}, 73 \%, \mathbf{5} \\
& \mathrm{R}=-\left(\mathrm{CH}_{2}\right)_{15} \mathrm{CH}_{3}, 70 \%, 6
\end{aligned}
$$

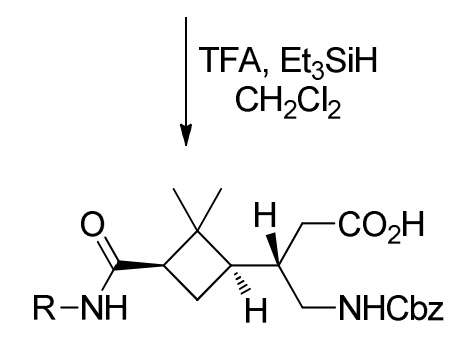

$\mathrm{R}=-\left(\mathrm{CH}_{2}\right)_{5} \mathrm{CH}_{3}$, quantitative, 7

$\mathrm{R}=-\left(\mathrm{CH}_{2}\right)_{15} \mathrm{CH}_{3}$, quantitative, 8

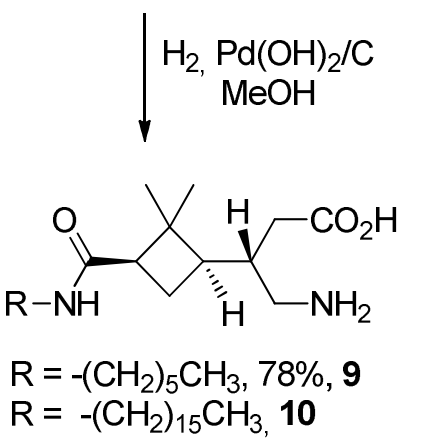

Scheme 1 
Prior to the synthesis of the target molecules, a model system with a hydrophobic alkyl chain of only six carbon atoms was synthesized to check the viability of both routes. To obtain the amine substituted model compound 3, a three step sequence was carried out (Scheme 1). First of all, the carboxylic acid was reduced to alcohol by means of $\mathrm{BH}_{3}$ in THF under reflux for 24 hours obtaining 2 in $80 \%$ yield. Then, the alcohol in 2 was converted into a mesylate using mesyl chloride in $\mathrm{CH}_{2} \mathrm{Cl}_{2}$ in the presence of triethylamine. This mesylate was used directly in the following step without purification. It was refluxed with hexylamine in acetonitrile to afford diprotected amino acid $\mathbf{3}$ in 57\% yield over the two steps. The same procedure was applied to prepare compound 4, except for the use of hexadecylamine instead of hexylamine, although in this case the yield of the last two steps dropped to $20 \%$. This could be related to the steric hindrance that the gem-dimethyl substitution in the cyclobutane confers to the molecule. Realizing that the yield in the target product was very poor and that larger quantities of material were needed to carry out the surfactant physico-chemical tests, this synthetic route was not useful for our purposes and, therefore, we decided to focus our efforts in the synthesis of amide derivatives $\mathbf{5}$ and $\mathbf{6}$.

The route started with compound $\mathbf{1}$, which was subjected to carboxylic acid activation as an acyl chloride using oxalyl chloride, to then couple the resulting intermediate with hexylamine, as a model reagent, obtaining compound $\mathbf{5}$ in $73 \%$ yield. When the same procedure was applied using hexadecylamine instead of the model amine, product 6 was obtained in $70 \%$ yield. As expected, yields herein were higher than in the first synthetic route due to less severe steric requirements of the coupling reaction with respect to the second order substitution process.

The model compound, 5, was transformed into amphiphile $\mathbf{9}$ to check the feasibility of the synthesis. Selective removal of tert-butyl ester was carried out using trifluoroacetic acid (TFA) in the presence of triethylsilane in dichloromethane, acid 7 being obtained quantitatively. After that, catalytic hydrogenation of the benzyl carbamate in the presence of $\mathrm{Pd}(\mathrm{OH})_{2}$ in $\mathrm{MeOH}$ resulted in compound 9 in $78 \%$ yield.

The same procedure was applied to the synthesis of amphiphile 10, starting from fully protected amino acid 6. Deprotection of the carboxyl group was accomplished with TFA to yield $\mathbf{8}$ in quantitative yield. Then, hydrogenolysis of the benzyl carbamate led to the formation of what was expected to be exclusively free $\gamma$-amino acid 10. Nevertheless, high resolution mass spectrometry in positive and negative mode and elemental analysis of this sample (see Experimental Section for details) revealed the presence of not only $\mathbf{1 0}$ but also salt $\mathbf{1 1}$ (Scheme 2), which would come from some TFA left in the hydrogenation step of $\mathbf{8}$. The proportion was calculated to be $0.35: 0.65$ of $\mathbf{1 0}+\mathbf{1 1}$. Attempts to eliminate 
residual acid after this step by lyophilisation were unfruitful. It is to note that the much lower molecular weight of TFA compared with $\mathbf{7}$ favours the salt formation even in the presence of a very small amount of TFA. The mixture was tried to be fully converted into $\mathbf{1 1}$ by stirring in dichloromethane in the presence of trifluoroacetic acid but the amount of $\mathbf{1 1}$ was never increased suggesting that the mixture composition corresponds to the acid-base equilibrium ratio (Scheme 2).

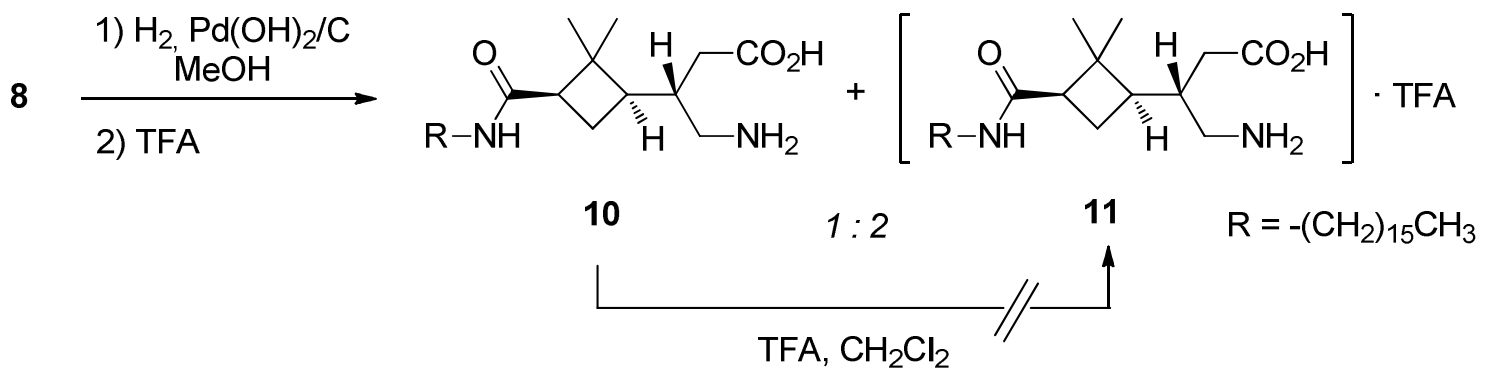

Scheme 2.

\subsection{Study of the mixture $(10+11)$ as surfactant.}

A preliminary test was carried out to evaluate the solubility of the obtained mixture $(\mathbf{1 0}+\mathbf{1 1})$ in water. The first assays determined that when an aqueous $2.5 \cdot 10^{-4} \mathrm{M}$ solution was prepared and shaken, foam appeared. This is a first sign of good behaviour as surfactant.

Then, $\mathrm{pH}$ measurements were performed to get more insight about the sample that contained the mixture $(\mathbf{1 0}+\mathbf{1 1}) .1 .002 \mathrm{~g}$ of a $0.0514 \mathrm{wt} \%$ solution of the surfactant were titrated with a $0.0039 \mathrm{wt} \% \mathrm{NaOH}$ solution $(\sim 1 \mathrm{mM})$ under a nitrogen atmosphere to avoid carbonation. The inflection point would correspond to the titration of the carboxylic acid proton of the trifluoroacetate salt $11\left(6.5 \cdot 10^{-6}\right.$ moles of $\mathrm{NaOH}$ added). Taking into account the different molecular weights of the two products and the total mass of the titrated mixture the results are in good agreement with the molar ratio for the two species inferred by the elemental analysis (Figure 1). 


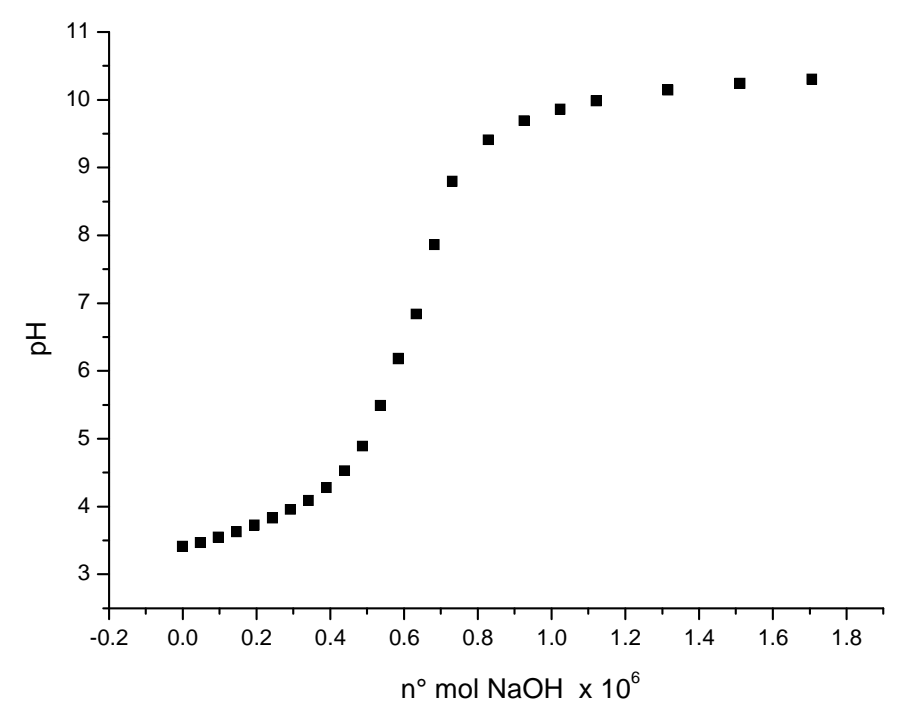

Figure 1. Titration of the surfactant mixture $(\mathbf{1 0}+\mathbf{1 1})$ with $\mathrm{NaOH}$.

The surface tension $(\gamma)$ of small volumes of the surfactant mixture $(\mathbf{1 0}+\mathbf{1 1})$ was measured using a homemade pendant drop tensiometer. ${ }^{16}$ Surface tension was followed as a function of time until equilibrium was reached (not appreciable variation of $\gamma$ ) which happened within 5-6 h from sample preparation. Care was taken to ensure a saturated humidity atmosphere to prevent evaporation. Temperature was maintained at $25.0 \pm 0.5^{\circ} \mathrm{C}$. Surface tension of the mixture decreased progressively upon increasing concentration (Figure 2) until a break above which it almost leveled to a constant value $\left(\sim 35 \mathrm{mN} \cdot \mathrm{m}^{-1}\right)$. The break occurs at a concentration of $2.4 \cdot 10^{-4} \mathrm{~mol} \cdot \mathrm{Kg}^{-1}$, as determined from the intersection of two fitting straight lines in the plot of $\gamma$ versus $\log \mathrm{C}$, which corresponds to the critical micellar concentration $(\mathrm{cmc})$ of the mixture. Concentrations were calculated taking into account the weighted average molar mass of the mixture 0.35:0.65 of $(\mathbf{1 0}+\mathbf{1 1})$ (i.e. $\left.526.83 \mathrm{~g} \cdot \mathrm{mol}^{-1}\right)$. This value of $\mathrm{cmc}$ is in good agreement with the value obtained in the preliminary foaming experiment, where the maximum foaming is usually observed just above the value of $c m c^{17}$. This value of $c m c, 2.4 \cdot 10^{-4} \mathrm{~mol} \cdot \mathrm{Kg}^{-1}$, is in the expected range of an ionic surfactant bearing a $C_{16}$-alkyl chain ${ }^{18}$ but appears to be high if it is compared with zwitterionic surfactants of the similar hydrophobic chain length. For instance, $\mathrm{C}_{14} \mathrm{H}_{25} \mathrm{~N}^{+}\left(\mathrm{CH}_{3}\right)_{2} \mathrm{CH}_{2} \mathrm{COO}^{-}$has a cmc of $2.2 \cdot 10^{-4} \mathrm{~mol} \cdot \mathrm{Kg}^{-1}$ or $\mathrm{C}_{14} \mathrm{H}_{25} \mathrm{~N}^{+}\left(\mathrm{CH}_{3}\right)_{2} \mathrm{CH}_{2} \mathrm{SO}_{3}{ }^{-}$has a $\mathrm{cmc}$ of $3.2 \cdot 10^{-4} \mathrm{~mol} \cdot \mathrm{Kg}^{-1} \cdot{ }^{19}$ Based on the hydrophobicity of the hydrocarbon chain and the presence of the cyclobutane group between the amide and the terminal zwitterionic group, one would have expected this product to have a lower $c m c$, this could be related to significant hydration of the amide group. 


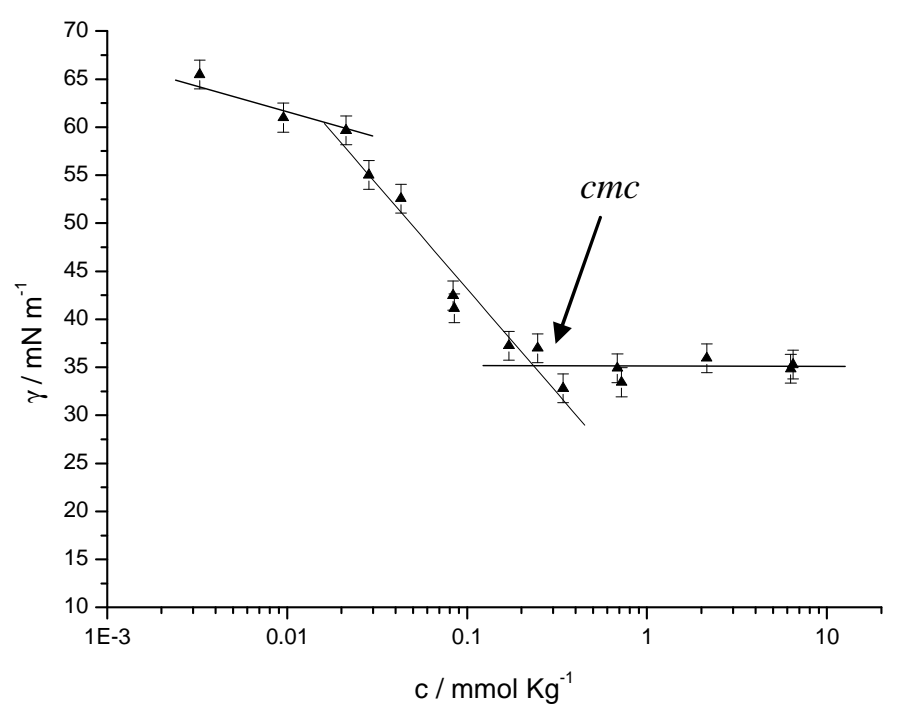

Figure 2. Plot of surface tension as a function of surfactant concentration for $(\mathbf{1 0}+\mathbf{1 1})$ mixture in water at $25^{\circ} \mathrm{C}$.

This mixture presents also the other characteristic to be considered as a surfactant, that is, selfaggregation. This is shown by the significant X-ray scattering observed in $19 \mathrm{mmol} \cdot \mathrm{Kg}^{-1}$ solutions, well above the $\mathrm{cmc}$ as observed from the above results. The experimental scattering pattern obtained at $25^{\circ} \mathrm{C}$ is shown in Figure 3 as a function of scattering vector modulus. It is apparent an increase of intensity at small $\mathrm{q}$ and a bump at intermediate $\mathrm{q}$. The fitting of several models did not result in perfect fitting, partly because of the low signal to noise ratio due to the low concentration. However, reasonable fitting was obtained using oligolamellar structures with a repetition distance of $3.7 \mathrm{~nm}$ and a few (2.5) correlated lamellae and using a core-shell ribbon model with a persistence length longer than $100 \mathrm{~nm}$ and width of $40 \mathrm{~nm}$. Both models give a similar fitting quality, in part because at a local level both correspond to flat lamellae. Both models result in similar hydrophobic thicknesses that would correspond to only $1.2 \mathrm{~nm}$, implying strong interdigitation of the hydrophobic chains and an area per molecule of $1.2 \mathrm{~nm}^{2}$. This value of area per molecule would be reasonable for the polar head to comprise not only the zwiterionic group but also the amide group, agreeing with the previous observation of low hydrophobicity introduced by the cyclobutane group. Whether the observed break in the surface tension plot corresponds to a monomer to micelle or monomer to vesicle transition cannot be decided with the present data and is out of the scope of the present article. 


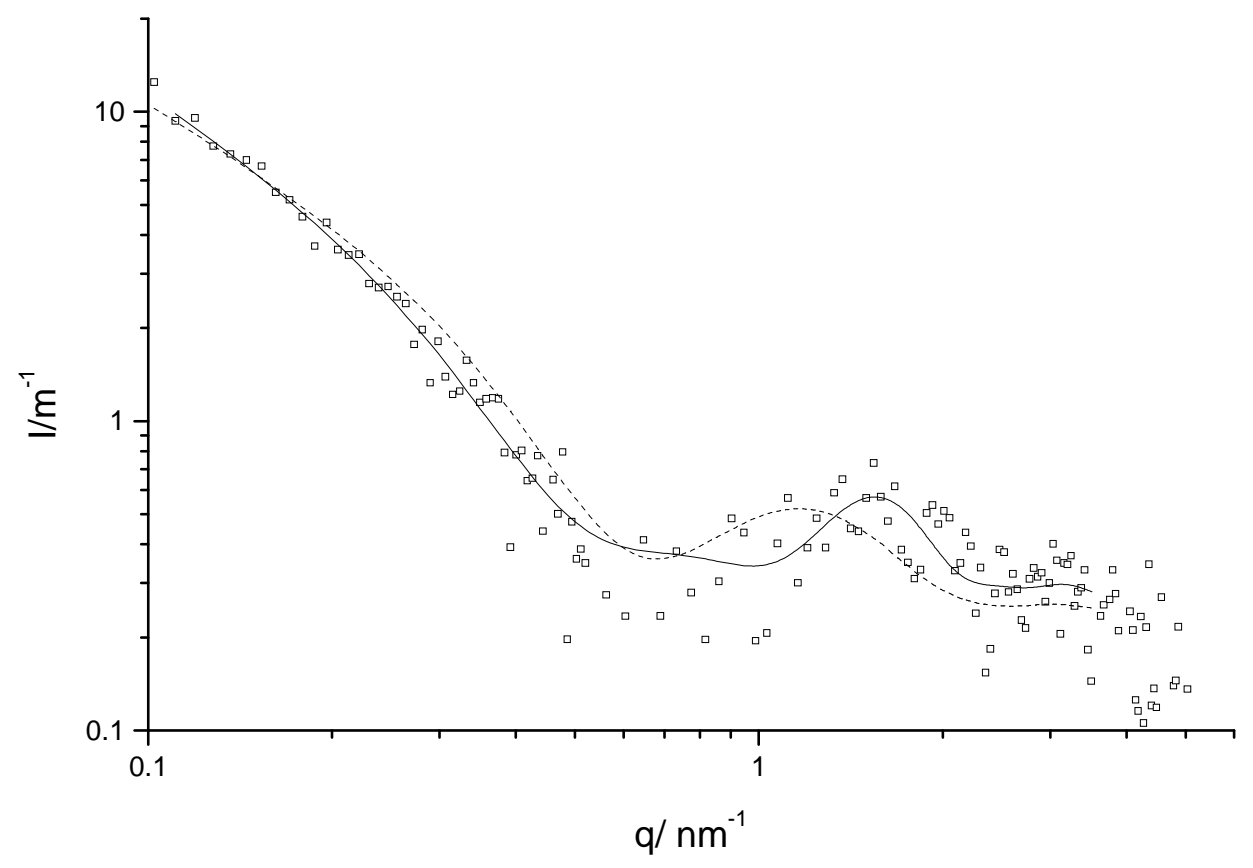

Figure 3. SAXS intensity corresponding to $19 \mathrm{mmol} \cdot \mathrm{Kg}^{-1}(\mathbf{1 0}+\mathbf{1 1})$ mixture in water at $25{ }^{\circ} \mathrm{C}$. The full line corresponds to the best fit result for oligolamellar structures and the dashed line corresponds to a core-shell ribbon model. From $\mathrm{q}=0.5 \mathrm{~nm}^{-1}$ onward the experimental points have been adjacent averaged to reduce noise.

\section{Conclusion}

Several new enantiopure cyclobutane derivatives containing a $\gamma$-amino acid function in a side-chain and additional $C_{6}$ or $C_{16}$-alkyl chains have been synthesized from a chiral precursor prepared, in turn, from ()-verbenone. Introduction of the alkyl substituents has been achieved more efficiently by means of amide formation instead of amine alkylation involving a $S_{N} 2$ process. This result is explained by the severe steric hindrance imposed by the gem-dimethyl group on the cyclobutane moiety. The basicity of the primary amine in the $\gamma$-amino acid function and that of the amide led to the unexpected formation of a TFA salt obtained jointly with the free amine in an approximate 2:1 proportion that presumably corresponds to the equilibrium ratio. Studies on this mixture suggest that it behaves as an efficient surfactant, the critical micellar concentration being $2.4 \cdot 10^{-4} \mathrm{~mol} \mathrm{Kg}^{-1}$. At moderate concentrations, the presence of oligolamellar structures has been observed. 


\section{Experimental}

\section{1. (3S)-tert-Butyl-4-benzyloxycarbonylamino-3-((1'R,3'R)-3'-hydroxymethyl-2',2'-}

dimethylcyclobutyl) butanoate, 2.

To a solution of acid $1(111 \mathrm{mg}, 0.3 \mathrm{mmol})$ in anhydrous THF $(0.5 \mathrm{~mL})$ was added a $1 \mathrm{M}$ solution of $\mathrm{BH}_{3}$ in THF $(0.5 \mathrm{~mL}, 0.4 \mathrm{mmol}, 1.5 \mathrm{eq})$. The mixture was heated to reflux under nitrogen atmosphere for $24 \mathrm{~h}$. Excess hydride was eliminated by slow addition of methanol $(1 \mathrm{~mL})$ and water $(3 \mathrm{~mL})$. The resultant solution was extracted with dichloromethane and the combined extracts were dried over $\mathrm{MgSO}_{4}$. Solvents were removed at reduced pressure, and the residue was chromatographed (ethyl acetate -hexane 1:1) to provide alcohol 2 as colourless oil $(85.4 \mathrm{~g}, 80 \%$ yield $)$. $[\alpha]_{\mathrm{D}}=-18.6\left(c 1.1, \mathrm{CHCl}_{3}\right)$; IR (ATR): 3339, 2952, 1789, 1520, 1455, $1367 \mathrm{~cm}^{-1} ;{ }^{1} \mathrm{H}$ NMR $\left(250 \mathrm{MHz}, \mathrm{CDCl}_{3}\right): \delta 1.02\left(\mathrm{~s}, 3 \mathrm{H}, \mathrm{CH}_{3}\right)$, $1.16\left(\mathrm{~s}, 3 \mathrm{H}, \mathrm{CH}_{3}\right), 1.44\left(\mathrm{~s}, 9 \mathrm{H},{ }^{t} \mathrm{Bu}\right), 1.61-1.76(\mathrm{~m}, 1 \mathrm{H}), 1.78-1.90(\mathrm{~m}, 1 \mathrm{H}), 1.96-2.09$ (complex absorption, 4H), 2.19-2.30 (m, 1H), 2.90-3.05 (m, 1H), 3.18-3.31 (m, 1H), 3.49-3.65 (c.a., 2H), 5.035.29 (c.a., $3 \mathrm{H}, \mathrm{CH}_{2} \mathrm{Bn}, \mathrm{NH}$ ), 7.30-7.41 (c.a., 5H, $\left.\mathrm{H}_{\mathrm{Ar}}\right) ;{ }^{13} \mathrm{C} \mathrm{NMR}\left(90 \mathrm{MHz}, \mathrm{CDCl}_{3}\right.$ ): $\delta$ 16.0, 24.0, 25.37, 28.1, 31.7, 37.3, 39.8, 42.7, 43.9, 44.0, 63.3( $\left.\mathrm{CH}_{2} \mathrm{OH}\right), 66.5,80.9,128.1$, 128.4, 136.7, 156.5, 172.4; HRMS Calcd for $\mathrm{C}_{23} \mathrm{H}_{35} \mathrm{NNaO}_{5}(\mathrm{M}+\mathrm{Na})^{+}: 428.2407$. Found, 428.2418.

\section{2. (3S)-tert-Butyl-4-benzyloxycarbonylamino-3-((1'R,3'R)-3'-hexylaminomethyl-2',2'-dimethyl- cyclobutyl)butanoate, 3 .}

Alcohol 2 (88 mg, $0.22 \mathrm{mmol})$ was dissolved in anhydrous $\mathrm{CH}_{2} \mathrm{Cl}_{2}(2 \mathrm{~mL})$ and the resulting solution was cooled down with an ice bath. After that, triethylamine $(45 \mu \mathrm{L}, 0.32 \mathrm{mmol})$ and mesyl chloride $(22 \mu \mathrm{L}$, $0.28 \mathrm{mmol}$ ) were subsequently added and the reaction was stirred at $0{ }^{\circ} \mathrm{C}$ for $1 \mathrm{~h}$. The resultant solution was extracted with dichloromethane, and the combined extracts were dried over $\mathrm{MgSO}_{4}$. Solvents were removed at reduced pressure to afford crude mesylate (100 $\mathrm{mg}$, 95\% yield) that was immediately used in the next step without purification. To the solution of mesylate $(100 \mathrm{mg}, 0.21 \mathrm{mmol})$ in anhydrous $\mathrm{CH}_{3} \mathrm{CN}(4 \mathrm{~mL})$ under nitrogen atmosphere were added $\mathrm{Et}_{3} \mathrm{~N}(40 \mu \mathrm{L}, 0.32 \mathrm{mmol})$ and hexylamine (60 $\mu \mathrm{L}, 0.3 \mathrm{mmol}$ ). The mixture was stirred at reflux for $24 \mathrm{~h}$. The solvent was evaporated under vacuum and diluted with saturated aqueous $\mathrm{NaHCO}_{3}(5 \mathrm{~mL})$. This was extracted with $\mathrm{CH}_{2} \mathrm{Cl}_{2}(3 \times 5 \mathrm{~mL})$ dried over $\mathrm{MgSO}_{4}$ and evaporated at reduced pressure. The residue was chromatographed (ethyl acetate hexane, 1:2 to 2:1) to afford pure 3 as yellow oil (58 mg, 57\% yield). $[\alpha]_{\mathrm{D}}=-14.4$ (c 1.2, $\mathrm{CHCl}_{3}$ ); IR (ATR): 2925, 2856, 1719, 1514, 1455, 1366,1245 cm ${ }^{-1}$; ${ }^{1} \mathrm{H}$ NMR $\left(250 \mathrm{MHz}, \mathrm{CDCl}_{3}\right): \delta 0.87-0.90(\mathrm{t}, 3 \mathrm{H}$, $\mathrm{CH}_{3}$ ), 0.98 (s, 3H), 1.14 (s, 3H), 1.19-1.36 (c.a., 10H, $-\mathrm{CH}_{2^{-}}$), 1.45 (s, 9H, $\left.{ }^{t} \mathrm{Bu}\right), 1.55-1.76(\mathrm{~m}, 1 \mathrm{H})$, 1.82-2.17 (c.a., 3H), 2.19-2.33 (m, 1H), 2.38-2.72 (c.a., 4H), 2.90-3.07 (m, 1H), 3.16-3.37 (m, 1H), 5.03-5.26 (c.a., 3H, $\left.\mathrm{CH}_{2} \mathrm{Bn}, \mathrm{NH}\right), 7.31-7.43$ (c.a., 5H, $\left.H_{\mathrm{Ar}}\right) ;{ }^{13} \mathrm{C} \mathrm{NMR}\left(90 \mathrm{MHz}, \mathrm{CDCl}_{3}\right.$ ): 14.2, 16.5, 
22.9, 27.4, 28.1, 28.5, 30.1, 31.7, 32.1, 37.5, 40.3, 42.2, 43.1, 44.9, 50.5, 50.7, 66.9, 81.2, 128.5, 128.9, 137.1, 156.9, 172.7; HRMS Calcd for $\mathrm{C}_{29} \mathrm{H}_{48} \mathrm{~N}_{2} \mathrm{O}_{4}(\mathrm{M}+\mathrm{Na})^{+}$: 489.3687. Found, 489.3683.

\section{3. (3S)-tert-Butyl-4-benzyloxycarbonylamino-3-((1'R,3'R)-3'-hexadecylamino-methyl)-2',2'-di-} methylcyclobutyl)butanoate, 4 .

To a solution of mesylate $\left(65 \mathrm{mg}, 0.13 \mathrm{mmol}\right.$ ) (prepared as explained for 4.2 ) in anhydrous $\mathrm{CH}_{3} \mathrm{CN}$ (2 $\mathrm{mL})$ under nitrogen atmosphere were added $\mathrm{Et}_{3} \mathrm{~N}(30 \mu \mathrm{L}, 0.22 \mathrm{mmol})$ and hexadecylamine (47 mg, 0.19 $\mathrm{mmol})$. The mixture was stirred at reflux for $24 \mathrm{~h}$. The solvent was evaporated under vacuum and diluted with saturated aqueous $\mathrm{NaHCO}_{3}(5 \mathrm{~mL})$. This was extracted with $\mathrm{CH}_{2} \mathrm{Cl}_{2}(3 \times 5 \mathrm{~mL})$ dried over $\mathrm{MgSO}_{4}$ and evaporated at reduced pressure. The residue was chromatographed (ethyl acetate-hexane, 1:4 to 2:1) to afford pure 4 as colorless oil (25 mg, 30\% yield). ${ }^{1} \mathrm{H}$ NMR (250 MHz, $\left.\mathrm{CDCl}_{3}\right): \delta 0.87-0.91$ (t, 3H), 1.06 (s, 3H, $\mathrm{CH}_{3}$ ), 1.19-1.36 (c.a., 27H, $-\mathrm{CH}_{2^{-}}, 3 \mathrm{H}, \mathrm{CH}_{3}$ ), 1.36-1.54 (c.a., $11 \mathrm{H},{ }^{t} \mathrm{Bu},-\mathrm{CH}_{2^{-}}$), 1.88-2.11 (c.a., 5H), 2.23-2.36 (c.a., 1H), 2.48-2.69 (c.a., 5H), 2.77-3.12 (c.a, 2H), 3.18-3.29 (c.a., 1H), 4.89-5.38 (c.a., 3H, $\mathrm{CH}_{2} \mathrm{Bn}, \mathrm{NH}$ ), 7.31-7.43 (c.a., 5H, HAr). LMRS (ESI+, m/z, \%) Calcd for $\mathrm{C}_{38} \mathrm{H}_{66} \mathrm{~N}_{2} \mathrm{NaO}_{5}$ $(\mathrm{M}+\mathrm{Na})^{+}:$637.5. Found, 637.1.

\section{4. (3S)-tert-Butyl-4-benzyloxycarbonylamino-3-((1'R,3' $R)-3^{\prime}$-hexylcarbamoyl-2',2'-dimethyl-} cyclobutyl)butanoate, 5 .

To a solution of acid 1 (370 mg, $0.88 \mathrm{mmol})$ in anhydrous $\mathrm{CH}_{2} \mathrm{Cl}_{2}, \mathrm{Et}_{3} \mathrm{~N}(0.15 \mathrm{~mL}, 1.06 \mathrm{mmol})$, oxalyl chloride (0.53 mL, $1.06 \mathrm{mmol})$ and 3 drops of DMF, were subsequently added. The mixture was stirred at room temperature for $2 \mathrm{~h}$. Then, hexylamine $(0.13 \mathrm{~mL}, 0.97 \mathrm{mmol})$ was added and the resultant solution was stirred at room temperature for $8 \mathrm{~h}$. Solvents were removed under reduced pressure and the crude of reaction was extracted with dichloromethane $(4 \times 10 \mathrm{~mL})$, and the organic extracts were dried over magnesium sulfate. The residue was chromatographed (ethyl acetate-hexane, 1:2 to 2:1) to afford pure 5 as colorless oil (123 mg, $73 \%$ yield). $[\alpha]_{\mathrm{D}}=+5.1\left(c 0.9, \mathrm{CHCl}_{3}\right)$; IR (ATR): 3308, 2928, 1706, 1647, 1528, 1455, $1366 \mathrm{~cm}^{-1} ;{ }^{1} \mathrm{H}$ NMR $\left(250 \mathrm{MHz}, \mathrm{CDCl}_{3}\right): \delta 0.84-0.96\left(\mathrm{t}, 3 \mathrm{H}, \mathrm{CH}_{3}\right), 1.01\left(\mathrm{~s}, 3 \mathrm{H}, \mathrm{CH}_{3}\right)$, 1.27 (s, 3H, $\mathrm{CH}_{3}$ ), 1.31-1.38 (c.a., $\left.-\mathrm{CH}_{2^{-}}, 5 \mathrm{H}\right), 1.45$ (s, 9H, $\left.{ }^{t} \mathrm{Bu}\right), 1.50-1.55$ (m, 1H), 1.65-1.84 (m, 2H), 1.88-2.11 (c.a., 4H), 2.16-2.31 (m, 1H), 2.38-2.55 (m, 1H), 2.98-3.14 (m, 1H), 3.18-3.38 (c.a., 3H), 5.04-5.33 (c.a., 3H, $\left.\mathrm{CH}_{2} \mathrm{Bn}, \mathrm{NH}\right), 7.32-7.42$ (c.a., 5H, $\mathrm{HAr}$ ); ${ }^{13} \mathrm{C} \mathrm{NMR}\left(90 \mathrm{MHz}, \mathrm{CDCl}_{3}\right): \delta 14.2,17.0$, 22.9, 24.5, 26.8, 28.5, 30.1, 31.7, 31.8, 37.6, 39.7, 42.8, 44.2, 47.6, 53.8, 67.0, 81.2, 128.2, 128.9, 137.1, 156.9, 171.6, 172.5; HRMS Calcd for $\mathrm{C}_{29} \mathrm{H}_{46} \mathrm{~N}_{2} \mathrm{NaO}_{5}(\mathrm{M}+\mathrm{Na})^{+}$: 525.3299. Found, 525.3304.

4.5. (3S)-tert-Butyl-4-benzyloxycarbonylamino-3-((1'R,3'R)-3'-hexadecylcarbamoyl-2',2'-dimethylcyclobutyl)butanoate, 6 . 
To a solution of acid 1 (310 mg, $0.74 \mathrm{mmol})$ in anhydrous $\mathrm{CH}_{2} \mathrm{Cl}_{2}(15 \mathrm{~mL}), \mathrm{Et}_{3} \mathrm{~N}(0.15 \mathrm{~mL}, 1.08 \mathrm{mmol})$, oxalyl chloride $(0.44 \mathrm{~mL}, 0.88 \mathrm{mmol})$ and 3 drops of DMF, were subsequently added. The mixture was stirred at room temperature for $2 \mathrm{~h}$. Then, hexadecylamine $(230 \mathrm{mg}, 0.95 \mathrm{mmol})$ was added and the resultant solution was stirred at room temperature for $8 \mathrm{~h}$. Solvents were removed under reduced pressure and the crude of reaction was extracted with dichloromethane $(4 \times 10 \mathrm{~mL})$ and the organic extracts were dried over $\mathrm{MgSO}_{4}$. The residue was chromatographed (ethyl acetate-hexane, 1:1) to afford pure 6 as colorless oil (330 mg, $70 \%$ yield). $[\alpha]_{\mathrm{D}}=+1.2\left(c 1.0, \mathrm{CHCl}_{3}\right) ;{ }^{1} \mathrm{H}$ NMR $\left(250 \mathrm{MHz}, \mathrm{CDCl}_{3}\right): \delta$ 0.82-0.95 (t, 3H, CH $), 1.00$ (s, 3H, $\mathrm{CH}_{3}$ ), 1.13-1.37 (c.a., $\left.28 \mathrm{H},-\mathrm{CH}_{2^{-}}, 3 \mathrm{H}, \mathrm{CH}_{3}\right), 1.44$ (s, 9H, $\left.{ }^{t} \mathrm{Bu}\right), 1.68-$ 2.08 (c.a., 5H), 2.13-2.33 (m, 1H), 2.38-2.53 (m, 1H), 2.95-3.13 (m, 1H), 3.16-3.44 (c.a., 3H), 5.00-5.58 (c.a., 4H, $\mathrm{CH}_{2} \mathrm{Bn}, \mathrm{NH}$ ), 7.30- 7.41 (c.a., 5H, HAr); ${ }^{13} \mathrm{C} \mathrm{NMR} \mathrm{(90} \mathrm{MHz,} \mathrm{CDCl}_{3}$ ): 14.5, 17.0, 23.1, 27.3, 28.5, 29.7, 30.1, 30.2, 31.7, 32.3, 37.6, 39.7, 42.8, 44.6, 67.0, 81.3, 128.5, 128.9, 137.1, 156.9, 171.6, 172.4. HRMS Calcd for $\mathrm{C}_{39} \mathrm{H}_{66} \mathrm{~N}_{2} \mathrm{NaO}_{5}(\mathrm{M}+\mathrm{Na})^{+}$: 665.4864. Found, 665.4851.

\section{6. (3S)-4-Benzyloxycarbonylamino-3-((1'R,3'R)-3'-hexylcarbamoyl-2',2'-dimethyl-cyclobutyl)-} butanoic acid, 7.

A mixture containing compound $5(66.2 \mathrm{mg}, 0.13 \mathrm{mmol})$, trifluoroacetic acid $(0.13 \mathrm{~mL}, 1.69 \mathrm{mmol})$ and triethyl silane $(50 \mu \mathrm{L}, 0.31 \mathrm{mmol})$ in anhydrous dichloromethane $(2 \mathrm{~mL})$ was stirred at room temperature for $18 \mathrm{~h}$. Solvent was evaporated and the excess of trifluoroacetic acid was removed by liophilization affording acid 7 as a yellowish oil $\left(79 \mathrm{mg}\right.$, quantitative yield). $[\alpha]_{\mathrm{D}}=+15.4(c \quad 1.3$, $\mathrm{CHCl}_{3}$ ); IR (ATR): 3322, 2928, 1703, 1638, 1536, 1455, $1371 \mathrm{~cm}^{-1} ;{ }^{1} \mathrm{H}-\mathrm{NMR}\left(250 \mathrm{MHz}, \mathrm{CDCl}_{3}\right): \delta$ 0.87-0.92 (t, 3H, $\mathrm{CH}_{3}$ ), 0.99 (s, 3H, $\mathrm{CH}_{3}$ ), 1.24 (s, 3H, $\mathrm{CH}_{3}$ ), 1.29-135 (c.a., 6H,-CH $\mathrm{2}^{-}$), 1.38-1.56 (c.a., 2H), 1.59-1.93 (m, 2H), 1.97-2.13 (c.a., 2H), 2.17-2.36 (m, 1H), 2.37-2.56 (m, 1H), 2.81-3.43 (c.a., 4H), 5.00-5.57 (c.a., 4H, $\mathrm{CH}_{2} \mathrm{Bn}, \mathrm{NH}$ ), 7.28- 7.54 (c.a., 5H, $H_{\mathrm{Ar}}$ ); ${ }^{13} \mathrm{C} \mathrm{NMR}\left(90 \mathrm{MHz}, \mathrm{CDCl}_{3}\right.$ ): 14.4, 17.1, 22.9, 24.1, 26.9, 30.1, 31.6, 31.8, 35.9, 37.6, 39.8, 42.8, 44.0, 47.6, 67.3, 128.7, 128.9, 136.7, 157.4, 172.0, 177.3. HRMS Calcd for $\mathrm{C}_{29} \mathrm{H}_{38} \mathrm{~N}_{2} \mathrm{NaO}_{5}(\mathrm{M}+\mathrm{Na})^{+}: 469.2673$. Found, 469.2674.

\section{7. (3S)-4-Benzyloxycarbonylamino-3-((1'R,3' $R)$-3'-hexadecylcarbamoyl-2',2'-di-methyl-} cyclobutyl)butanoic acid, 8.

A mixture containing compound $6(220 \mathrm{mg}, 0.34 \mathrm{mmol})$, trifluoroacetic acid $(0.34 \mathrm{~mL}, 4.41 \mathrm{mmol})$ and triethyl silane $(0.14 \mathrm{~mL}, 0.88 \mathrm{mmol})$ in anhydrous dichloromethane $(4 \mathrm{~mL})$ was stirred at room temperature for $18 \mathrm{~h}$. Solvent was evaporated and the excess of trifluoroacetic acid was removed by liophilization affording acid 8 as a colorless oil (200 mg, quantitative yield). $[\alpha]_{\mathrm{D}}=+14.2(c$ 1.4, $\mathrm{CHCl}_{3}$ ); IR (ATR): 3320, 2918-2850, 1705, 1636, 1532, 1466, $1160 \mathrm{~cm}^{-1} ;{ }^{1} \mathrm{H}$ NMR $\left(250 \mathrm{MHz}, \mathrm{CDCl}_{3}\right)$ : $\delta$ 0.87-0.92 (t, 3H, $\left.\mathrm{CH}_{3}\right), 0.95$ (s, 3H, $\left.\mathrm{CH}_{3}\right), 1.25-1.40$ (a.c., $\left.30 \mathrm{H},-\mathrm{CH}_{2^{-}}, 3 \mathrm{H}, \mathrm{CH}_{3}\right), 1.42-1.62(\mathrm{~m}, 1 \mathrm{H})$, 
1.63-1.94(m, 1H), 1.95-2.40 (c.a., 3H), 2.44-2.67 (m, 1H), 2.84-3.40 (c.a., 4H), 5.00-5.48 (c.a., 3H, $\mathrm{CH}_{2} \mathrm{Bn}, \mathrm{NH}$ ), 5.63-5.83 (broad., $\left.1 \mathrm{H}, \mathrm{NH}\right)$ 7.30- 7.47 (c.a., 5H, $\left.\mathrm{H}_{\mathrm{Ar}}\right) ;{ }^{13} \mathrm{C} \mathrm{NMR}\left(90 \mathrm{MHz}, \mathrm{CDCl}_{3}\right): 14.5$, 17.1, 23.1, 27.3, 29.8, 30.1, 31.5, 32.3, 35.9, 37.7, 40.1, 42.4, 43.1, 47.5, 67.4, 128.5, 128.9, 136.7, 157.5, 172.4, 176.63. HRMS Calcd for $\mathrm{C}_{35} \mathrm{H}_{58} \mathrm{~N}_{2} \mathrm{NaO}_{5}(\mathrm{M}+\mathrm{Na})^{+}$: 609.4238. Found, 609.4249.

\section{8. (3S)-4-Amino-3-((1'R,3'R)-3'-hexylcarbamoyl-2',2'-dimethylcyclobutyl)butanoic acid, 9.}

Compound 7 (44.8 mg, $0.10 \mathrm{mmol})$ in methanol $(5 \mathrm{~mL})$ was hydrogenated under 5 atmospheres of pressure in the presence of $30 \% \mathrm{Pd}(\mathrm{OH})_{2} / \mathrm{C}(13 \mathrm{mg}, 2 \% \mathrm{Pd}$ in weight $)$ overnight. The reaction mixture was filtered through Celite and solvent was removed under reduced pressure to provide $9(24.4 \mathrm{mg}, 78 \%$ yield) as a colourless oil. $[\alpha]_{\mathrm{D}}=+5.3,\left(c 1, \mathrm{CH}_{3} \mathrm{OH}\right) ;{ }^{1} \mathrm{H} \mathrm{NMR}\left(250 \mathrm{MHz}, \mathrm{CD}_{3} \mathrm{OD}\right): \delta 0.90-0.95(\mathrm{t}, 3 \mathrm{H}$, $\mathrm{CH}_{3}$ ), 1.00 (s, 3H, $\mathrm{CH}_{3}$ ), 1.30 (s, 3H, $\mathrm{CH}_{3}$ ), 1.33-135 (c.a.,-- $\mathrm{CH}_{2^{-}}, 6 \mathrm{H}$ ), 1.43-1.61 (c.a., 2H), 1.84-2.04 (c.a., 3H), 2.11-2.38 (m, 1H), 2.39-2.65 (m, 1H), 2.66-3.01 (c.a., 2H), 3.03-3.27 (c.a., 2H), 3.29-3.34 (m, 1H); ${ }^{13} \mathrm{C}-\mathrm{RMN}\left(90 \mathrm{MHz}, \mathrm{CD}_{3} \mathrm{OD}\right): 13.4,16.3,18.4,22.6,22.81,26.7,29.5,30.6,31.7,35.9,39.3$, 42.5, 44.2, 46.4, 50.5, 172.7. HRMS Calcd for $\mathrm{C}_{17} \mathrm{H}_{32} \mathrm{~N}_{2} \mathrm{NaO}_{3}(\mathrm{M}+\mathrm{Na})^{+}$: 335.2305. Found, 335.2310.

\section{9. (3S)-4-Amino-3-((1'R,3'R)-3'-hexadecylcarbamoyl-2',2'-dimethylcyclobutyl) butanoic acid} and (3S)-3-carboxy-2-((1R,3R)-3-hexadecylcarbamoyl-2',2'-dimethylcyclobutyl)propan-1aminium trifluoroacetate, 10 and 11.

Compound 8 (200 mg, $0.34 \mathrm{mmol})$ in methanol $(10 \mathrm{~mL})$ was hydrogenated under 5 atmospheres of pressure in the presence of $30 \% \mathrm{Pd}(\mathrm{OH})_{2} / \mathrm{C}(60 \mathrm{mg}, 2 \% \mathrm{Pd}$ in weight $)$ overnight. The reaction mixture was filtered through Celite ${ }^{\circledR}$ and solvent was removed under reduced pressure to provide amine 10 (180 $\mathrm{mg}$ ) as a white solid and its corresponding salt 11. ${ }^{1} \mathrm{H} \mathrm{NMR}\left(250 \mathrm{MHz}, \mathrm{CDCl}_{3}\right): \delta 0.89-0.91(\mathrm{t}, 3 \mathrm{H}$, $\mathrm{CH}_{3}$ ), 0.97 (s, 3H, $\mathrm{CH}_{3}$ ), 1.06-1.41 (c.a., 27H, - $\mathrm{CH}_{2^{-}}, 3 \mathrm{H}, \mathrm{CH}_{3}$ ), 1.59 (c.a., 2H), 1.95-2.07 (c.a., 3H), 2.21-2.66 (c.a., 2H), 2.82-3.03 (c.a., 2H), 3.10-3.32 (c.a., 3H), 4.89-5.21 (broad., 2H, NH); ${ }^{13} \mathrm{C}$ NMR (90 MHz, $\mathrm{CD}_{3} \mathrm{OD}$ ): 13.3, 16.0, 17.72, 18.07, 22.4, 26.7, 29.1, 29.4, 29.5, 30.1, 31.5, 31.8, 39.1, 42.2, 43.1, 45.9, 50.1, 172.1. ${ }^{13} \mathrm{C}$ NMR (90 MHz, DMSO): 14.4, 17.1, 22.5, 22.9, 26.8, 28.2, 29.2, 29.5, 29.7, 31.2, 31.7, 34.4, 37.9, 38.8, 42.0, 43.0, 46.1, 100.0, 170.4, 173.8. HRMS Calcd for 10: $\mathrm{C}_{27} \mathrm{H}_{51} \mathrm{~N}_{2} \mathrm{O}_{3}$ (M1): 451.3905. Found, 451.3900; $\mathrm{C}_{27} \mathrm{H}_{53} \mathrm{~N}_{2} \mathrm{O}_{3}(\mathrm{M}+1)^{+}:$453.4051; Found, 453.4060. HRMS Calcd for 11: $\mathrm{C}_{29} \mathrm{H}_{52} \mathrm{~F}_{3} \mathrm{~N}_{2} \mathrm{O}_{5}$ (M-1): 565.3907. Found, 565.3839; $\mathrm{C}_{27} \mathrm{H}_{51} \mathrm{~N}_{2} \mathrm{O}_{3}$ ( $\left(\mathrm{M}^{-} \mathrm{C}_{2} \mathrm{~F}_{3} \mathrm{O}_{2}-2\right)^{-}$: 451.3905. Found, 451.3900. $\mathrm{C}_{27} \mathrm{H}_{53} \mathrm{~N}_{2} \mathrm{O}_{3}\left(\mathrm{M}-\mathrm{C}_{2} \mathrm{~F}_{3} \mathrm{O}_{2}\right)^{+}$: 453.4051; Found, 453.4060. Anal. calcd for 0.35:0.65 (10 + 11) mixture: C, 64.52; N, 10.07\%; H, 5.32\%. Found: C, 64.47; N, 10.58\%; H, 5.01\%. 


\subsection{SAXS measurements}

Small-Angle X-ray Scattering (SAXS) measurements were carried out using a S3-MICRO (Hecus X-ray systems GMBH Graz, Austria) coupled to a GENIX-Fox 3D X-ray source (Xenocs, Grenoble), which provides a detector focussed $\mathrm{x}$-ray beam with $\lambda=0.1542 \mathrm{~nm} \mathrm{Cu} \mathrm{K \alpha} \alpha$-line with more than $97 \%$ purity and less than $0.3 \% \mathrm{~K}_{\beta}$. Transmitted scattering was detected using a PSD 50 Hecus. Temperature was controlled by means of a Peltier TCCS-3 Hecus. The samples were inserted in a flow-through glass capillary $1 \mathrm{~mm}$ diameter with $20 \mu \mathrm{m}$ wall thickness. The SAXS and WAXS scattering curves are shown as a function of the scattering vector modulus:

$$
q=\frac{4 \pi}{\lambda} \cdot \sin \frac{\theta}{2}
$$

where, $\theta$ is the scattering angle. The $\mathrm{q}$ values with our setup ranged from $0.08 \mathrm{~nm}^{-1}$ to $6.0 \mathrm{~nm}^{-1}$. The system scattering vector was calibrated by measuring a standard silver behenate sample. Because of the use of a detector focused small beam (300 x $400 \mu \mathrm{m}$ full width at half maximum) the scattering curves are mainly smeared by the detector width. This mainly produces a widening of the peaks without noticeable effect on the peak position. The scattering curves for liquid samples have been background subtracted and put in absolute scale by comparison with a water sample scattering. ${ }^{20-21}$

The instrumentally smeared experimental SAXS curves were fitted to numerically smeared models for beam size and detector width effects. A least squares routine based on the Levenberg-Marquardt scheme was used. A model of core-shell ribbons (high aspect ratio ellipsoidal section cylinders ${ }^{22}$ ) and a model of bilayers based on the Modified Caillé Gaussian scheme was used. ${ }^{23-24}$

\section{Acknowledgments}

Imma Carrera is acknowledged for help in the measurement of surface tensions. Jaume Caelles from the SAXS-WAXS service at IQAC is acknowledged for the SAXS measurements. The authors thank financial support from Spanish Ministerio de Ciencia e Innovación (grant CTQ2010-15408/BQU and CTQ2010-14897) and Generalitat de Catalunya (grant 2009SGR-733 and 2009SGR-1331). 


\section{References}

1 Karsa, D. R. Industrial applications of surfactants IV; Royal Society of Chemistry, Cambridge, UK, 1999; Schramm, L. L; Stasiuk, E. N.; Marangoni, D. G. Annu. Rep. Prog. Chem., Sect. C, 2003, 99, 3.

2 For some reviews see: (a) Pérez, N.; Pérez, L.; Infante, M. R.; García, T. Green Chem. 2005, 7, 540; (b) Infante, M. R.; Pérez, L.; Morán, M. C.; Pons, R.; Mitjans, M.; Vinardell, M. P.; Garcia, M. T.; Pinazo, A. Eur. J. Lipid Sci. Technol. 2010, 112, 110; (c) Pinazo, A.; Pons, R.; Pérez, L.; Infante, M. R. Ind. Eng. Chem. Res. 2011, 50, 4805; (d) Chandra, N.; Tyagi, V.K. J. Dispersion Sci. Technol. 2012, DOI: 10.1080/01932691.2012.695967.

3 Foley, P.; Kermanshahi pour, A.; Beach, E. S.; Zimmerman, J. B. Chem. Soc. Rev. 2012, 41, 1499.

4 See for example: (a) Che, S.; Liu, Z.; Ohsuna, T.; Sakamoto, K.; Terasaki, O.; Tatsumi, T. Nature 2004, 429, 281; (b) Fireman-Shoresh, S.; Marx, S.; Avnir, D. Advanced Materials 2007, 19, 2145; (c) Yokoi, T.; Ogawa, K.; Lu, D.; Kondo, J. N.; Kubota, Y.; Tatsumi, T. Chem. Mater. 2011, 23, 2014.

5 Sorrenti, A.; Altieri, B.; Ceccacci, F.; Di Profio, P.; Germani, R.; Giansanti, L.; Savelli, G.; Mancini, G. Chirality 2012, 24, 78 .

6 See for example: (a) Otsuka, K.; Terabe, S. Encyclopedia of Chromatography (3 ${ }^{\text {rd }}$ Ed.) 2010, 1, 433; (b) Guebitz, G.; Schmid, M. G. J. Chromatog. A 2008, 1204, 140.

7 (a) Moglioni, A. G.; García-Expósito, E.; Moltrasio, G. Y.; Ortuño, R.M. Tetrahedron Lett. 1998, 39, 3593; (b) Moglioni, A. G.; García-Expósito, E.; Aguado, G. P.; Parella, T.; Branchadell, V.; Moltrasio, G. Y.; Ortuño, R. M. J. Org. Chem. 2000, 65, 3934.

8 Ortuño, R. M.; Izquierdo, S.; Hölenz, J.; Corbera, J.; Cuberes, R. PCT Int. Appl. (2008) WO 2008015266.

9 (a) Aguado, G. P.; Álvarez-Larena, Á.; Illa, O.; Moglioni, A. G.; Ortuño, R. M. Tetrahedron: Asymmetry 2001, 12, 25; (b) Aguado, G. P.; Moglioni, A. G.; Ortuño, R. M. Tetrahedron: Asymmetry 2003, 14, 217.

10 Aguado, G. P.; Moglioni, A. G.; García-Expósito, E.; Branchadell, V.; Ortuño, R. M. J. Org. Chem. 2004, 69, 7971. 
11 Torres, E.; Acosta-Silva, C.; Rúa, F.; Álvarez-Larena, Á.; Parella, T.; Branchadell, V.; Ortuño, R. M. Tetrahedron 2009, 65, 5669.

12 (a) Aguado, G. P.; Moglioni, A. G.; Brousse, B. N.; Ortuño, R. M. Tetrahedron: Asymmetry 2003, 14, 2445; (b) Aguilera, J.; Gutiérrez-Abad, R.; Mor, A.; Moglioni, A. G.; Moltrasio, G. Y.; Ortuño, R. M. Tetrahedron: Asymmetry 2008, 19, 2864; (c) Aguilera, J.; Moglioni, A. G.; Moltrasio, G. Y.; Ortuño, R. M. Tetrahedron: Asymmetry 2008, 65, 5669; (d) Aguilera, J.; Cobos, J. A.; Gutiérrez-Abad, R.; Acosta, C.; Nolis, P.; Illa, O.; Ortuño, R. M. Eur. J. Org. Chem. 2013, 10.1002/ejoc.201300066.

13 (a) Rouge, P. D.; Moglioni, A.G.; Moltrasio, G.Y.; Ortuño, R.M. Tetrahedron: Asymmetry 2002, 14, 193; (b) Moglioni, A. G.; Brousse, B. N.; Álvarez-Larena, Á.; Moltrasio, G. Y.; Ortuño, R. M. Tetrahedron: Asymmetry 2002, 13, 451.

14 (a) Gutiérrez-Abad, R.; Carbajo, D.; Nolis, P.; Acosta-Silva, C.; Cobos, J. A.; Illa, O.; Ortuño, R. M. Amino Acids 2011, 41, 673; (b) Gorrea, E.; Carbajo, D.; Gutiérrez-Abad, R.; Illa, O.; Branchadell, V.; Royo, M.; Ortuño, R. M. Org. Biomol Chem. 2012, 10, 4050.

15 Gutiérrez-Abad, R.; Illa, O.; Ortuño, R. M. Org. Lett. 2010, 12, 3148.

16 Pinazo, A.; Angelet, M.; Pons, R.; Lozano, M.; Infante, M. R.; Pérez, L. Langmuir 2009, 25, 7803.

17 Rossen, M.J. Surfactants and Interfacial Phenomena, Wiley-Interscience, New Jersey, 2004, pp 285.

18 Mukerjee, P.; Mysels, K. J. Critical Micelle Concentrations of Aqueous Surfactant Systems, National Bureau of Standards, NSRDS-NBS 36, U.S. Government Printing Office, Washington, DC, 1971.

19 Zajac, J.; Chorro, C.; Lindheimer, M.; Partyka S. Langmuir 1997, 13, 1486.

20 Orthaber, D.; Bergmann, A.;Glatter, O. J. Appl.Cryst. 2000, 33, 218.

21 Pérez, L.; Pinazo, A.; Infante, M.R.; Pons, R. J. Phys. Chem. B 2007, 111, 11379.

22 Pedersen, J.S. Adv. Colloid Interface Sci. 1997, 70, 171.

23 Pabst, G.; Rappolt, M.; Amenitsch, H.; Laggner, P. Phys. Rev. E 2000. 62, 4000.

24 Rodriguez, G.; Cocera, M.; Rubio, L.; Alonso, C.; Pons, R.; Sandt, C.; Dumas, P.; Lopez-Iglesias, C.; de la Maza, A.; Lopez, O. Phys. Chem. Chem. Phys. 2012, 14, 14523. 
